Діагностично-результативний компонент системи професійної підготовки здобувачів вищої освіти передбачає контроль, моніторинг й оцінювання результатів їхнього навчання на основі діагностування якості наданих закладом освітніх послуг, а також рівнів задоволеності ними студентів шляхом їхнього опитування, самооцінки продуктів освітньої діяльності.

\title{
Література:
}

1. Змеев С. И. Андрагогика: основы теории и технологии обучения взрослых. Москва : Персэ, 2003. 206 с.

2. Jarvis P. Adult Education and Lifelong Learning. Theory and practice. 3rd. edn. London: Routledge, 2004. 374 p.

DOI https://doi.org/10.30525/978-9934-588-80-8-2.64

\section{ОРГАНІЗАЦИЙОО-МЕТОДИЧНІ ЗАСАДИ СТВОРЕННЯ СПРИЯТЛИВИХ УМОВ ДЛЯ НАВЧАННЯ В ЗАКЛАДАХ ВИЩОЇ ОСВІТИ (ЗВО) СТУДЕНТІВ З ГЛИБОКИМИ ПОРУШЕННЯМИ ЗОРУ}

\author{
Серпутько Г. П. \\ кандидат філологічних наук, \\ доцент кафедри офтальмопедагогіки та офтальмопсихології \\ Наиіональний педагогічний університет імені М. П. Драгоманова \\ Гребенюк Т. М. \\ кандидат психологічних наук, \\ доцент кафедри офтальмопедагогіки та офтальмопсихології \\ Національний педагогічний університет імені М. П. Драгоманова \\ Федоренко М. I. \\ кандидат педагогічних наук, \\ доиент кафедри спеціальної психології та медицини \\ Начіональний педагогічний університет імені М. П. Драгоманова \\ м. Київ, Украӥна
}

На виконання вимог доступності до навчання осіб з інвалідністю, задекларованих у статті 24 «Освіта» Конвенції ООН про права осіб з інвалідністю, спрямоване й національне освітнє законодавство та низка підзаконних актів. 
Зокрема, постановою Кабінету Міністрів України від 10 липня 2019 року № 635 затверджено Порядок організації інклюзивного навчання у закладах вищої освіти (ЗВО), який визначає вимоги до організації інклюзивного навчання у закладах вищої освіти незалежно від їх підпорядкування та форми власності, з метою реалізації права осіб з особливими освітніми потребами на здобуття вищої освіти, післядипломної освіти 3 урахуванням їхніх покликань, інтересів i здібностей [3].

Об'єктом нашого дослідження є освітній процес у закладах вищої освіти України, який, на вимогу Конвенції ООН про права осіб 3 інвалідністю, низки нормативно-правових документів та освітнього законодавства України, має забезпечувати доступні умови для навчання студентів, зокрема з глибокими порушеннями зору.

У своєму дослідженні ми послуговуємося досить конкретним терміном «студенти 3 глибокими порушеннями зору» (незрячі студенти, які використовують під час навчання рельєфно-крапковий шрифт Брайля та спеціальні (адаптивні) комп'ютерно-інформаційні технології), який, проте, не закріплений в національному законодавстві, але найкраще, на нашу думку, відображає потреби і труднощі у навчанні зазначеної категорії студентів 3ВО.

Чи не найважливішим аспектом $є$ створення у $3 В О$ ресурсного центру навчально-методичного супроводу таких студентів.

Зазначені центри можуть здійснювати кілька напрямів діяльності, зокрема, психолого-педагогічний, соціальний i технічний. На нашу думку, саме навчально-методичний супровід поєднує педагогічну підтримку та технічне забезпечення навчальної діяльності студентів 3 глибокими порушеннями зору. А це, передусім:

- розробка (з урахуванням особливостей сприймання навчального матеріалу студентами 3 глибокими порушеннями зору) спеціального навчально-методичного забезпечення, зокрема, опорних конспектів лекцій $з$ виділенням основних інформаційно значущих фрагментів тексту, методичних рекомендацій тощо;

- організація самостійної роботи студентів, можливість підготовки до практичних, семінарських i лабораторних занять, технічне $\mathrm{i}$ методичне забезпечення (користування медіатекою, засвоєння методів самостійного аналізу, структуризації, обробки та фіксації інформації тощо);

- надання викладачами необхідної консультаційної допомоги;

- забезпечення наскрізності навчально-наукової роботи студентів: від рефератів, курсових робіт до підготовки магістерської кваліфікаційної роботи, доповідей для участі у наукових студентських 242 
конференціях тощо. Більш того, із запровадженням форматів дистанційної та заочної участі у наукових заходах, можливості участі в них таких студентів розширюються до загальнодержавних i міжнародних масштабів;

- використання спеціальних технологій та технічних засобів для репрезентації навчального матеріалу в адаптованому до потреб студентів вигляді: вербальному (звуковому), тактильному, тобто у різних доступних форматах [2, с. 86]. Ресурсні центри, які здійснюють супровід студентів 3 глибокими порушеннями зору, мають бути обладнані хоча б кількома комп'ютерними тифлокомплексами. До складу комп'ютерного тифлокомплексу входять: комп'ютер зі спеціальним адаптивним програмним забезпеченням мовленнєвого та тактильного виводу інформації з монітору (не менше 17»), оснащений відповідним спеціальним периферійним обладнанням (брайлівський дисплей), сканером, акустичними колонками, навушниками 3 мікрофоном [2, с. 87].

Ефективне поєднання технічного забезпечення та педагогічного керівництва освітньою діяльністю студентів з глибокими порушеннями зору створює сприятливі навчально-методичні умови для якісного фахового навчання студентів з глибокими порушеннями зору.

Питаннями соціально-психологічної адаптації студентів 3 порушеннями зору до умов навчання у ЗВО займалася Т. М. Гребенюк, яка у своєму дослідженні зокрема описувала деякі групи труднощів у навчанні студентів 3 порушеннями зору в ЗВО [1]. Праці С. В. Федоренко присвячувалися питанням наступності та безперервності у здобутті середньої і вищої освіти особами з порушеннями зору [6], окремі методичні рекомендації, базовані на науковому підгрунті, зустрічаються у науково-методичному посібнику Т. М. Гребенюк, Г. П. Серпутько, Є. П. Синьової [2]. У колективній монографії за редакцією П. М. Таланчука описано досвід зі створення сприятливих умов навчання для осіб 3 інвалідністю у Відкритому міжнародному університеті розвитку людини «Україна» та розкрито основні теоретико-методологічні технології такого навчання [5].

Доступ до ресурсного центу навчально-методичного супроводу студентів з глибокими порушеннями зору повинні мати студенти різних факультетів і спеціальностей університету. Зокрема, в Національному педагогічному університеті імені М. П. Драгоманова найдоцільнішим має бути функціонування зазначеного центру саме на факультеті спеціальної та інклюзивної освіти, де діє кафедра офтальмопедагогіки та офтальмопсихології, викладачі якої можуть надавати студентам фахову підтримку. В інформаційно-комп’ютерному центрі факультету наявне 
комп'ютерне обладнання зі спеціальним програмним забезпеченням i пристосуванням. Якщо вдаватися до кількісного співвідношення, то на факультеті спеціальної та інклюзивної освіти навчається найбільша кількість студентів з глибокими порушеннями зору. Щороку від 5 до 10 незрячих студентів здобувають дефектологічну освіту. Хоча й на інших факультетах час від часу здобувають педагогічну освіту студенти 3 глибокими порушеннями зору.

Найголовнішим чинником доступної освіти для студентів 3 глибокими порушеннями зору на сьогодні $є$ їх забезпечення необхідними навчально-методичними матеріалами у різних форматах: електронних, озвучених та надрукованих рельєфно-крапковим шрифтом Брайля [4, с. 68].

Якщо більшу частину навчально-методичної літератури з гуманітарних дисциплін можна перевести в електронну форму чи озвучити, то серед низки гуманітарних дисциплін вагомі труднощі для незрячих студентів становить вивчення деяких іноземних мов зі складною лінгвоструктурою, а також опанування давніх мов, чи не найважчими серед яких є давньогрецька й старослов'янська мови, які є обов'язковими для вивчення студентів-філологів. Зокрема, щодо вивчення давніх мов незрячими студентами, то найефективнішим видається сприймання текстів і лексики давньої мови на конкретно-чуттєвій основі, тобто на дотик, на основі читання книг, надрукованих рельєфно-крапковим шрифтом Л. Брайля. Проте, держава наразі не забезпечує таких студентів вищої і професійної освіти навчальними підручниками в доступних форматах, тому ЗВО покликані вирішувати ці проблеми самотужки. Таким чином ресурсні центри продукуватимуть найпотужніші результати у створенні доступних умов для здобуття якісної фахової освіти студентами з інвалідністю, зокрема 3 глибокими порушеннями зору, в Україні.

Саме в ресурсному центрі навчально-методичного супроводу студентів з глибокими порушеннями зору можна буде створювати такі необхідні для якісного навчання студентів підручники і посібники за допомогою сучасного брайлівського принтера Brailleboox, адже викладачі факультету спеціальної та інклюзивної освіти і зокрема кафедри офтальмопедагогіки та офтальмопсихології НПУ імені М. П. Драгомагнова зможуть фахово це робити без залучення сторонньої допомоги. Згодом діяльність центру може поширюватися й на інші категорії студентів з інвалідністю, які потребують створення сприятливих умов для якісного навчання та оволодіння обраним фахом. Адже факультет спеціальної та інклюзивної освіти НПУ імені М. П. Драгоманова має для цього необхідні фахові ресурси. 


\section{Література:}

1. Гребенюк Т. М. Соціально-психологічна адаптація інвалідів 3 вадами зору до навчання у вищих навчальних закладах : автореф. дис. ... канд. психол. наук : 19.00.08. Київ, 2008. 20 с.

2. Основи психолого-педагогічного супроводу студентів 3 порушеннями зору: науково-методичний посібник / Є. П. Синьова, Т. М. Гребенюк, Г. П. Серпутько; за ред. С. П. Синьової. Київ : Вид-во НПУ імені М. П. Драгоманова, 2015. 153 с.

3. Про затвердження Порядку організації інклюзивного навчання у закладах вищої освіти : Постанова КМУ від 10 липня 2019 р. № 635. URL: $\quad$ https://www.kmu.gov.ua/ua/npas/pro-zatverdzhennya-poryadkuorganizaciyi-inklyuzivnogo-navchannya-u-zakladah-vishchoyi-osvitii100719?fbclid=IwAR0cYpiE3Wk6Up2xtk6Iwk9N4mivLxw4QtXijpuwic5 gmK1zxjT1RONNwE4

4. Серпутько Г. П. Шляхи створення сприятливих умов для навчання у закладах вищої освіти студентів із глибокими порушеннями зору (на прикладі вивчення старослов'янської мови). Науковий часопис Національного педагогічного університету імені М.П. Драгоманова. Серія 5. Педагогічні науки : реалії та перспективи. 2020. Випуск 72. T. 2. C. $66-69$.

5. Теоретико-методологічні засади та технології інклюзії у ЗВО. Досвід університету «Україна» : кол. моногр. / Таланчук П. М., Чайковський М. С. та ін.; за наук. ред. П. М. Таланчука. Київ : Університет «Україна», 2018. 481 с.

6. Федоренко С. В. Реалізація системи безперервної освіти у взаємозв'язку середньої школи для дітей з порушеним зором та вищої школи // Актуальні проблеми навчання та виховання людей 3 особливими потребами : зб. наук. праць / за заг. ред.: П. М. Таланчука, Г. В. Онкович. Київ : Університет «Україна», 2002. С. 87-91. 